\title{
Vertical distribution of Spbaeroma terebrans (Isopoda) on submerged stationary structures
}

\author{
Puthenveetil A. John \\ Oceanographic Laboratory, Ernakulam-6, South India
}

\begin{abstract}
KURZFASSUNG: Vertikale Verbreitung von Sphaeroma terebrans (Isopoda) an untergetauchten Halenbefestigungsanlagen. Im Hafengebiet von Cochin $\left(76^{0} 14^{\prime} \mathrm{E} ; 9^{0} 57^{\prime} \mathrm{N}\right)$ wurde die vertikale Verbreitung des holzbohrenden Isopoden Spbaeroma terebrans untersucht. Sphaeroma lebt, wie der Mollusk Martesia striata, im Holz untergetauchter Pfähle. Unmittelbar nach dem Herauszichen von 12 Pierpfählen verschiedener Länge wurde das Verbreitungsmuster der Bohrlöcher beider Organismen registriert. Es stellte sich dabei heraus: 7 Pfähle wiesen Sphaeroma-Löcher bis zu einer Tiefe von $45 \mathrm{~cm}$ unter dem Hochwasserstand auf, 5 bis $\mathrm{zu}$ einer solchen von $60 \mathrm{~cm}$. Martesia-Löcher dagegen traten an den erwähnten 7 Pfählen erst ab $60 \mathrm{~cm}$ Tiefe auf, an den anderen 5 erst ab $75 \mathrm{~cm}$. Von diesen Tiefen bis zum Boden war Martesia der alleinige Bewohner. Im vertikalen Verbreitungsmuster der beiden Arten gibt es also praktisch keine Überlappungszone. Die Ursache für diese Segregation wird primär in der Raumkonkurrenz gesehen und in dem größeren Vermögen von Sphaeroma, gelegentliches Trockenfallen $\mathrm{zu}$ ertragen.
\end{abstract}

\section{INTRODUCTION}

In the Cochin Harbour, $76^{\circ} 14^{\prime} \mathrm{E}$ and $9^{\circ} 57^{\prime} \mathrm{N}$, jetty piles are pulled out for replacement after a service life of three to four years. These piles provide an excellent opportunity to study the vertical distribution of Sphaeroma and other boring organisms attacking the same $\log$. During the present investigation, twelve logs were examined soon after they were pulled out.

The burrows made by Sphaeroma can be easily distinguished from burrows made by other organisms on the basis of their external appearance. The external openings of Sphaeroma burrows are comparatively wide (3-4 $\mathrm{mm}$ in diameter), and the burrow itself is of uniform diameter throughout its length, whereas the external openings of Martesia burrows are comparatively small (1-2 $\mathrm{mm}$ in diameter). In most cases the distal ends of the shells slightly protrude through the opening.

For studying the number of burrows in a given surface area the number of burrows at each level was counted in an area 3 " $\times 1$ " $(7,6 \times 2,5 \mathrm{~cm})$, the greater distance being along the horizontal plane. All the numbers quoted represent averages of four counts in areas along four quadrants at each level. Since the intertidal zone appeared to be the region of intense attack, the counts were made $15 \mathrm{~cm}$ apart in this region and $30 \mathrm{~cm}$ apart below it. The data thus collected are given in the accompanying table. 


\section{RESULTS AND DISCUSSION}

From the table it will be seen that in all samples of timber examined, Sphaeroma is the sole occupant down to a depth of $45 \mathrm{~cm}$ from the high water level, the maximum density being noticed close to the high water level. Martesia make their first appearance on a few logs at a depth of $60 \mathrm{~cm}$, and in all cases where Martesia is present, Sphaeroma appear to be absent below $45 \mathrm{~cm}$ under high water level. But on five $\log$ on which Martesia are absent at a depth of $60 \mathrm{~cm}$, a few specimens of Sphaeroma are present down to that level. Below $60 \mathrm{~cm}$ depth Sphaeroma is totally absent, and only Martesia is noticed down to the mud level. It will thus be seen that on submerged vertical structures in the Cochin Harbour, where both Spbaeroma and Martesia occur together, they seem to show a marked degree of segregation, Sphaeroma never occurring at the same level as Martesia.

Previous records on the vertical distribution of Sphaeroma are rather scanty. BARrows (1919) has observed that Sphaeromidae are largely shallow water forms. However, Gerstaecker and OrTMANN, as quoted by Barrows (1919), are of the opinion that some marine species have been dredged from a depth of 75 fathoms. Pillai (1955) observed that the attack of Sphaeroma is heaviest in the intertidal zone. In the Australian waters, Sphaeroma quoyana was found to attack wood only between tide levels in some places but never exceeded two to three feet below low water level. During the present studies also, the author was able to collect $S$. terebrans from sunken pieces of wood obtained from depths of two to three meters. In one case Sphaeroma burrows were noticed at depths two meters below low water level on a stake pole, of which 10 meters were under water. But in both of the above instances, the water in the area was only slightly saline, thereby making Sphaeroma the only boring organism present on the timber at the time of observation.

Pillar (1955) has observed that Sphaeroma is capable of inhabiting waters shallower than those inhabited by the Molluscan borer Martesia because the young ones of Sphaeroma leave the brood pouch for fresh attack in a fairly advanced stage of development, and are therefore capable of withstanding occasional exposure, whereas the larvae of Martesia at the time of fresh settling are very delicate and must necessarily always be under water. This observation about the capacity of Sphaeroma to survive occasional exposure seems to be correct. It does not, however, explain why Sphaeroma avoids the deeper levels.

It is quite possible that the distribution of Sphaeroma is controlled to a very great extent by the availability of food. Recent investigations (LANE 1959, BECKER 1959) have shown that Limnoria depends to some extent for its food on the fungal growths along the sides of their burrows. In an unpublished paper on the habits, structure and development of $S$. terebrans, I have shown that even though cellulose digesting enzymes are present in the alimentary tract of this species, it is fully capable of carrying on its metabolic activities only with the addition of supplementary food in the form of algae and other suspended organic matter. Thus it may not be wrong to presume that the surface layer of water, which contains plenty of suspended organic particles, may favour the greater density of Sphaeroma in this region. But it will be noted that all the logs examined during the present study were pulled up 


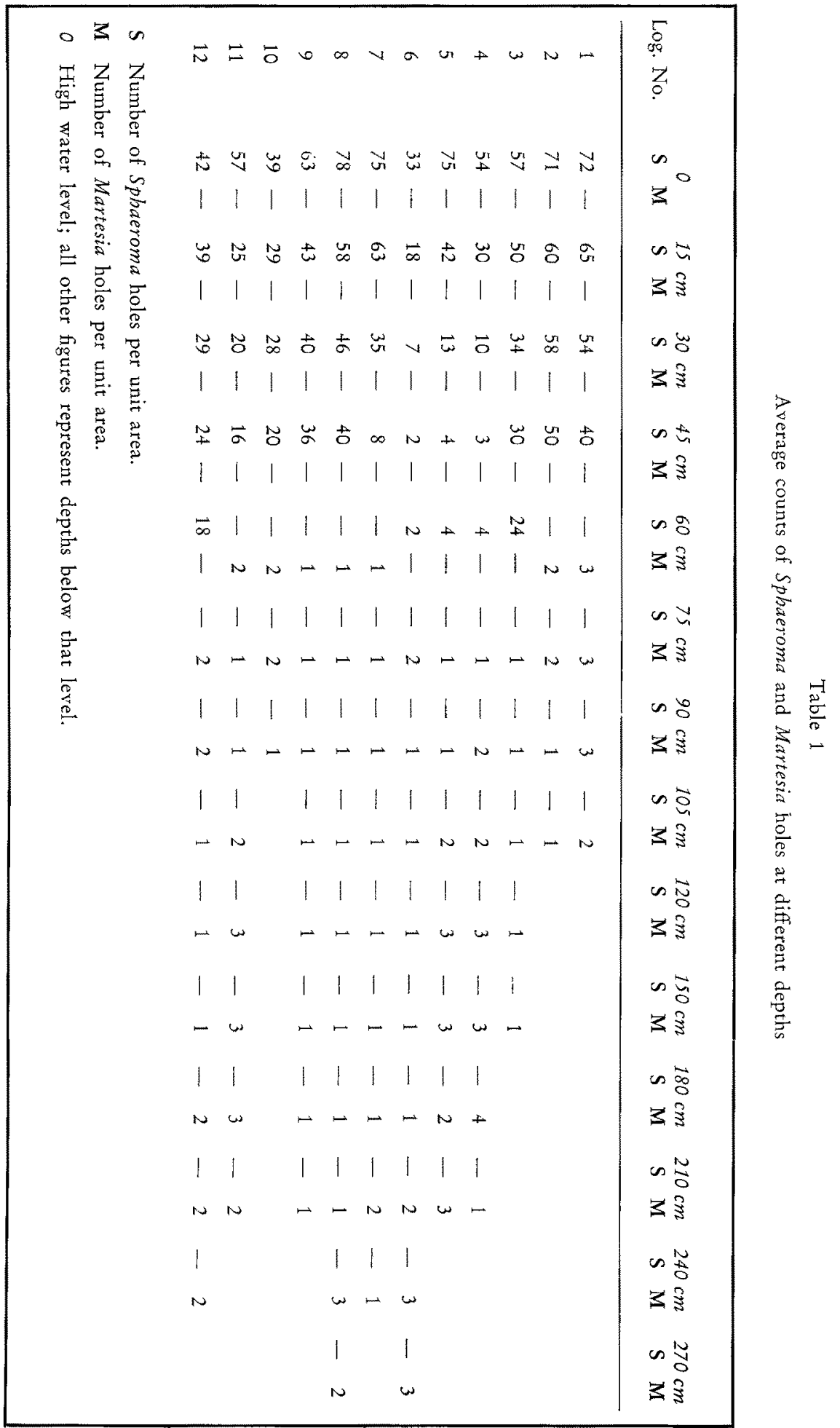


from very close to the shore, where the depth did not exceed three meters. In this region the water is homogenous in composition (salinity, $\mathrm{O}_{2}$ content, temp. and turbidity) along the entire depth, especially in view of the fact that water is constantly agitated by waves and tidal currents. Therefore there is no stratification of water in this region and hence no greater concentration of suspended organic particles towards the surface layer.

Moreover, the food of Martesia also consists of suspended organic matter and planktonic organisms. In spite of this situation, Martesia are found at greater depths than Sphaeroma. It is not quite likely therefore that food is the important factor determining the vertical distribution of these organisms.

On the other hand, it is more likely that competition for space is the chief factor which determines vertical distribution. As has already been stated, Sphaeroma is capable of withstanding prolonged exposure. Specimens have been kept alive in moist cloth for 12 to 16 hours. Martesia, however, is incapable of tolerating such exposure even for short intervals. Consequently, Martesia is restricted to regions which are permanently submerged, leaving the upper regions free for occupation by Sphaeroma. This view is supported by the fact that in regions of low salinity, where Martesia does not occur, Sphaeroma have been found two to three meters below low water level. It is therefore evident that the food habits of Sphaeroma and Martesia are more or less the same and that the chief factor which determines their distribution is the struggle for appropriate space.

\section{SUMMARY}

1. Sphaeroma terebrans and Martesia striata occur on jetty piles in the Conchin harbor ( $76^{\circ} 14^{\prime} \mathrm{E}$ and $\left.9^{0} 57^{\prime} \mathrm{N}\right)$.

2. On a given jetty pile or log, however, both species live at different depths. There is practically no overlap in their vertical distribution.

3. A total of twelve logs were examined. On seven of these logs Sphaeroma holes occured down to a depth of $45 \mathrm{~cm}$ below high water level, on the other five down to $60 \mathrm{~cm}$. Martesia holes, however, began to appear on the first seven logs at $60 \mathrm{~cm}$ depth and on the other five at $75 \mathrm{~cm}$ depth. From these levels they occured right down to the bottom (maximum depth: $270 \mathrm{~cm}$ ).

4. It is suggested that this vertical segregation is primarily caused by the greater capacities of Sphaeroma to withstand prolonged periods of exposure to air and by competition for space.

\section{ACKNOWLEDGEMENTS}

This study was carried out as part of a scheme sponsored by the Wood Preservation Branch of the Forest Research Institute and Colleges, Dehra Dun, for the protection of underwater wooden structures against the attack of marine organisms. I wish to express my sincere thanks to Dr. C. C. JoHN, formerly Professor of Marine Biology and Fisheries, University of Kerala, for his guidance and to Professor O. Kinne, Hamburg-Altona, for his kind suggestions concerning the preparation of this paper. 


\section{LITERATURE CI'TED}

BARrows, A. L., 1919. The occurrence of a rock boring isopod along the shore of San Francisco Bay. Calif. Publ. Zool. 19, 299-316.

BECKER, G., 1959. Biological investigations on marine borers in Berlin-Dahlem. Marine boring and fouling organisms. Friday Harbour Symposia, Univ. Washington Press, Seattle, 62-76.

Jornson, R. A., 1932. Protective Measures and Bark protection. Publ. Sydney Harbour Trust, 139-145.

LANE, C. E., 1959. The general histology and nutrition of Limnoria. Friday Harbour Symposia, Univ. Washington Press, Seattle, 34-46.

PillaI, N. K., 1955. Wood Boring Crustacea of Travancore. 1. Sphaeromidae. Bull. Centr. Res. Inst., Univ. Travancore. Ser. C. Nat. Sci. 6, 125-138. 